\title{
Achievement and Ascription: Fact or Fiction
}

\author{
"Castles in the clouds, flying by; \\ men will build them till they die; \\ don't they know it's all a lie, \\ tumbling castles make them cry; \\ still they try..."
}

Identity is shaped by thoughts, ideas, feelings and emotions; expressed in words, actions and expressions; and recorded for posterity in mentifacts and artifacts. "Paper" (or "plastic") identity, found on various identification cards, electronic databases, resumés and curriculum vitaes, is not necessarily be the same as the "flesh and blood" or real-life identity known best to those with whom face-to-face interaction takes place over long periods of time in various day-to-day situations.

Status is both achieved and ascribed, and the degree to which one or the other contributes more draws the thin line between the real and apparent. To achieve means "to carry out successfully (accomplish);" "to get or attain as a result of exertion (reach)," or "to attain a desired end or aim (to become successful)."2 To ascribe, on the other hand, comes from the restored spelling of the Middle English ascrive, etymologically derives from the Old French, ascrivre, "to attribute, inscribe," and the Latin ascribere "to write in, to add to in a writing", from ad-" "to" + scribere "to write." To ascribe is to refer to a supposed cause, source, or author, and "suggests an inferring of cause, quality or authorship" as in the case of "forged paintings formerly ascribed to masters."

Achievement rightfully bestows an earned "headship," implied in its etymology from the Old French, achever "to finish," from the phrase à chef (venir) "at an end, finished," the Vulgate Latin *accapare, from the Latin ad caput (venire). Literally, both the Old French and Latin phrases mean "to come to a head," from the Latin caput "head." Ascription is flattery at best; but worse when self-generated and perpetuated. Are vicarious experiences that become "personal accomplishments," casual visits and observations that become "further training and fellowships," comments and editing (even supervisory positions) that metamorphose into "research and co-authorships" any different from the fictitious medals of a dictator? Awards beget awards. Those who are thus preceded by reputation may loom "larger than life." Do such giants stand on feet of clay?

Our circles are a microcosm of the nation and world around us. Public servants who believe the fictions crafted by themselves and their coutillons continue to claim the right to rule (rather than the obligation to serve). Are we dazzled by the dream? What do we aspire for? Et tu?

\footnotetext{
"Castles in the Clouds" Lapeña JF, [unpublished song] Manila: 1978.

${ }^{2}$ Available from: http://www.merriam-webster.com/dictionary/achieve

${ }^{3}$ Available from: http://www.etymonline.com/index.php?search=ascribe\&searchmode=nl

${ }^{4}$ Available from: http://www.merriam-webster.com/dictionary/ascribe (italics mine)

${ }^{5}$ Available from: http://www.etymonline.com/index.php?search=achieve\&searchmode=nl

${ }^{6}$ Available from: http://apame.info/?id=07.

7 "Wherever you Go"The Weston Priory Monks [narration from the song] ๑1972

The Benedictine Foundation of the State of Vermont, Inc., Weston Priory, Weston, VT 05161-6400
}

The first meeting of the Asia Pacific Association of Medical Journal Editors (APAME) was held in Seoul, the Republic of Korea last May 45, 2008 co-hosted by the World Health Organization Western Pacific Regional Office. ${ }^{6}$ APAME's vision, it was agreed, would be to promote health care through the dissemination of quality health information in the Asia Pacific Region. The association also established the following aims:

1. To upgrade publishing standards of health journals and books, paper-based or electronic;

2. To develop an aggregated indexing system for health articles published in the Asia Pacific Region; and

3. To enhance optimal access to health articles.

The development of the Western Pacific Region Index Medicus (WPRIM) and the Global Health Library (GHL) are much-needed efforts to ensure the dissemination of and universal access to reliable health information essential to health development. These efforts will level the playing field for authors, editors, peer reviewers, publishers and subscribers in developing countries, elevating loco-regional research and publishing to the global arena. Following our continued compliance with established standards, we anticipate inclusion of the Philipp J Otolaryngol Head Neck Surg in the WPRIM.

Through its President Gil M. Vicente, and the Board of Trustees, our Society blazes new trails to lead us beyond the confines of self-directed concerns toward new horizons of hope for our various publics, present and future. Efforts aimed at health-promotion and disease-prevention, side by side with involvement in ecological and environmental concerns may prove to be as, or even more important, than the equally quixotic pursuit of cutting-edge diagnostic and therapeutic advances. What use are these when they are beyond the reach of most?

"When the time of our particular sunset comes, our 'thing,' our accomplishment, won't matter a great deal. But the clarity and concern with which we have loved others will speak with vitality of the great gift of life we have been to each other."7 